Research Article

\title{
Quality Assessment of Water from Some Selected Sources in Pokhara, Nepal
}

\section{Thaneshwor Subedi}

\author{
Associate Professor \\ Department of Chemistry, Prithvi Narayan Campus \\ Tribhuvan University \\ Email: thaneshworsubedi@gmail.com
}

Article History

Received 4 April 2021

Revised 10 August 2021

Accepted 12 November 2021

\begin{abstract}
The present study was carried out to analyze and compare the physicochemical properties of water from Seti Gandaki river, Kali stream, irrigation canal, bore well and potable sources in Pokhara Metropolitan-1, Kaski, Nepal by using standard techniques. Observed properties from different sources were compared to each other and with recommended standard World Health Organization (WHO) values. The result of the study showed that the large number of physical and chemical parameters such as color odor, temperature, specific gravity, relative turbidity, suspended solid (SS), total dissolved solid (TDS), total solid (TS), $p^{H}$, electrical conductivity (EC), alkalinity, carbonate, bicarbonate, residual sodium carbonate (RSC), boron, chloride, sulphate, nitrate and nitrite- $N$, calcium hardness, magnesium hardness, total hardness, oil and grease, phenol, surfactants were within the permissible limit of WHO. The observed color of river water and irrigation water was glacial creamy white due to excess of cream white colored suspended colloidal particles in water. The analyzed amount of iron for the sample from different sources was more than that of permissible limit of WHO standard and iron amount was much more for bore well sample. On the basis of analyzed result and WHO standard values, it was concluded that potable water, bore well water and stream water can be used for washing, bathing, irrigation, and industrial purposes after proper treatments. In this study, most of the physicochemical and organic parameters were also analyzed but not the microbiological species.
\end{abstract}

Keywords: Conductivity, hardness, Pokhara, surfactants, water pollutants

(C) The Author, published by JRCC, Janapriya Multiple Campus. 


\section{INTRODUCTION}

Water is the most important natural resources to all living organisms, ecological system, human health, food production and economic development. Pure water free from pollutants is required to keep healthy natural environment (Shukla, et al., 2013). The quality of water is decreasing day by day due to contamination of water by radioactive materials, sediments, organic pollutants, inorganic pollutant and thermal pollutants. Physical, chemical and biological parameters determine the quality of water (De, 2018). Polluted water causes many diseases in animals, plants, humans and may disturb the overall natural balance. Polluted water causes adverse effect on thermal plants, industries, and agricultural farming.

The objective of the study was to analyze physical and chemical characteristics of water samples from various sources; Seti Gandaki river, irrigation canal, Kali stream, bore well water and water from tape and then to compare these physicochemical parameters with each other and WHO standard values. In the present research, physicochemical properties like color, odor, specific gravity, turbidity, temperature, $\mathrm{P}^{\mathrm{H}}$, suspended solid (SS), total dissolved solid (TDS), total solid (TS), electrical conductivity (EC), alkalinity, calcium hardness, magnesium hardness, alkalinity, total hardness, residual sodium carbonate (RSC), carbonate ions, bicarbonate ions, boron, chloride, sulphate, nitrate, oil and grease, phenol and surfactant were analyzed in the chemistry laboratory of Prithvi Narayan Campus, Pokhara. Such types of comparable natural community related water analysis of various sources in particular area were not conducted and documented till the date. Therefore, such type of new comparative physicochemical analysis was carried out in Pokhara.

Different types of research related to water analysis has been conducted by various researchers. Analytical methods for irrigation water analysis have been described in Method Manual (Government of India, 2011). Vogel's text book of qualitative analysis presented the analytical techniques for hardness of water, heavy metals, cations and anions in water (Vogel, 1994). Physico-chemical properties of bore well water in Pokhara and chemical composition of irrigation water of Seti canal were also analyzed by the researcher (Subedi, 2018). Physicochemical properties of water from various source was compared by Shukla and friends (Shukla et al., 2012). Khopkar (2010) explained the gravimetric methods for the analysis of oil, grease and phenol in water. Warner, Levy, Harpp and Farruggia (2008) conducted their study on drinking water quality in Nepal's Kathmandu Valley: a survey and assessment of selected controlling site characteristics. In this research, 100 water samples from municipal taps, dug wells, tube wells, dhungedharas were studied for physical, chemical and organic parameters. 
Background documents for development of WHO guideline for drinking water quality (WHO, 2011) presented the permissible level of temperature $\left(12-25^{\circ} \mathrm{C}\right)$, TDS $(500-1000$ $\left.\mathrm{g} \mathrm{cm}^{-3}\right), \mathrm{P}^{\mathrm{H}}(6.5-8.5)$, EC $\left(400 \mu \mathrm{S} \mathrm{cm} \mathrm{cm}^{-1}\right)$, alkalinity $(500 \mathrm{ppm})$, calcium hardness $(100$ ppm), magnesium hardness (30 ppm), total hardness (500 ppm), Iron (0.3 ppm), chloride $(250 \mathrm{ppm})$ nitrate $(50 \mathrm{ppm})$, nitrite $(3 \mathrm{ppm})$, nitrate-N (11.3 ppm). National drinking water quality standard, 2062 BS, Government of Nepal, ministry of land reform and management, Singhadarbar Kathmandu, Nepal presented maximum concentration limit for $\mathrm{p}^{\mathrm{H}}(6.5-8.5)$, $\mathrm{EC}\left(1.5 \mu \mathrm{S} \mathrm{cm}^{-1}\right), \mathrm{NO}_{3}^{-}-\mathrm{N}-\mathrm{N}\left(11.3 \mathrm{mg} \mathrm{L}^{-1}\right), \mathrm{NO}_{2}-\mathrm{N}\left(0.913 \mathrm{mg} \mathrm{L}^{-1}\right), \mathrm{SO}_{4}^{--}\left(250 \mathrm{mg} \mathrm{L}^{-1}\right), \mathrm{Al}$ (0.2 $\left.\mathrm{mg} \mathrm{L}^{-1}\right)$, As (0.05 mg L-1), Ca (200 mg L $\left.\mathrm{m}^{-1}\right), \mathrm{Cd}\left(0.003 \mathrm{mg} \mathrm{L}^{-1}\right), \mathrm{Cu}\left(1 \mathrm{mg} \mathrm{L}^{-1}\right), \mathrm{Cr}(0.05$ $\left.\mathrm{mg} \mathrm{L}{ }^{-1}\right), \mathrm{Fe}\left(0.3 \mathrm{mg} \mathrm{L}^{-1}\right), \mathrm{Pb}\left(0.01 \mathrm{mg} \mathrm{L}^{-1}\right), \mathrm{Mn}\left(0.2 \mathrm{mg} \mathrm{L}^{-1}\right), \mathrm{Zn}\left(0.001 \mathrm{mg} \mathrm{L}^{-1}\right)$, E. coli bacteria $(0.0 \mathrm{CFU} / 100 \mathrm{ml})$, total coli form bacteria $(0.0 \mathrm{CFU} / 100 \mathrm{ml})$.

\section{MATERIALS AND METHODS}

Physicochemical analysis of water from various sources and their comparative study required a large number of apparatus, scientific equipments and analytical reagents (AR). The most important apparatus and equipment's were analytical balance of 4 digits, beakers, Buchner filtration apparatus, burette, centrifuge, conductivity meter, conical flask, desiccators, glass rod, glass wool, heating mantle, Kjeldhal distillation assembly, magnetic stirrer, muffle furnace, muslin cloth dish, nephelometer, $\mathrm{p}^{\mathrm{H}}$ meter, pipette, porcelain dish, separatory funnel, spectrophotometer, Soxhlet apparatus, spoon, stop watch, thermometer, tweezers, water bath, whatman-42 filter paper etc. Similarly, the most important chemicals required for this research were acetic acid, ammonia, ammonium acetate, 4- aminoantipyrine, ammonium chloride, azomethane- $\mathrm{H}$, barium chloride, boric acid, bromocresol green, buffer solution $\left(\mathrm{P}^{\mathrm{H}}: 4,7,10\right)$, calcium carbonate, calcon, chloroform, copper sulphate, eriochrome black-T(EBT) indicator, ethanol, ethylene diamineacetic acid, gum acecia, n-hexane, hydrochloric acid, hydroxylamine hydrochloride hydrazine sulphate, magnesium chloride, manganese sulphate, magnesium oxide, methyl orange, methyl ter-butyl ether (MTBE), mercuric chloride, murexide, phenolphthalein phosphoric acid, potassium chloride, potassium chromate, potassium ferricyanide $\left[\mathrm{K}_{3} \mathrm{Fe}(\mathrm{CN})_{6}\right]$, potassium hydroxide, potassium permanganate, potassium sulphate, sodium sulphate, silver nitrate, stannous chloride, sulphuric acid etc.

Prithvi Narayan Campus Pokhara and its neighboring area were selected as study area which was located at almost altitude $916 \mathrm{~m}$ from sea level with latitude 28.24 North and longitude 83.99 East. Samples of potable water, bore-well water were taken from campus area 
where as samples of irrigation water, river (Seti Gandaki) water and Kali stream water was taken from the nearest distance from the campus. Polypropylene bottles of two liter capacity were used for water sample collection. Before sample collection, all bottles were washed with $8 \mathrm{~N} \mathrm{HNO}_{3}$ followed by distilled water and were dried in an oven. These bottles were rinsed trice with the sample water, labeled with date, time and sampling source. Five collected samples were analyzed for physicochemical parameters by using specific analytical techniques.

The color of water samples was analyzed by visual comparison, platinum-cobalt (P-C), method and was expressed in PC units (Khopkar, 2012). Odour of water samples was measured in terms of its relative strength i.e. up to which dilution level, the sample remains detectable by human nose and expressed in threshold order number (TON). Specific gravity, a water quality parameter, was determined by using specific gravity bottle and electric balance and expressed in $\mathrm{gm} \mathrm{cm}^{-3}$. Temperature was measured by using Celsius thermometer on the sampling spot $\&$ expressed in degree. Relative turbidity was measured by laboratory based nephelometer or turbidity meter and expressed in NTU. The water quality parameter, suspended solid or fixed solid, was determined as dry residue obtained by filtering water sample through $2 \mathrm{~mm}$ pore size glass fiber. The weight loss on ignition of residue at $180^{\circ} \mathrm{C}$ is volatile solid. TDS was calculated by evaporating the filtrate and heating at $180^{\circ} \mathrm{C}$ in an electric oven for an hour. Total solid was calculated by evaporating to dryness \& heating at $105^{\circ} \mathrm{C}$ for an hour which was expressed in ppm (Khopkar, 2012). $\quad \mathrm{P}^{\mathrm{H}}$, a water quality parameter, of the samples was measured by using $\mathrm{P}^{\mathrm{H}}$ meter in sampling spot and expressed as hydrogen ion activity. Electrical conductivity (EC), a water quality parameter, as specific conductivity was measured by using conductivity meter and expressed as $\mu \mathrm{S} \mathrm{cm}^{-1}$ (APHA, 1985).

Alkalinity, an algal productive parameter, was calculated by titrimetric method by titration with standard $\mathrm{HCl}$ in presence of phenolphthalein for carbonate alkalinity at $\mathrm{P}^{\mathrm{H}} 8.3$ or methyl orange for bicarbonate alkalinity at $\mathrm{P}^{\mathrm{H}}=3.7$ and was expressed in $\mathrm{ppm}$ as $\mathrm{CaCO}_{3}$ (Khopkar, 2012). Calcium, magnesium and total hardness of sample were determined by complexometric titration using ethylene diaminetetraacetic acid at required $\mathrm{P}^{\mathrm{H}}$ (10) and expressed in ppm (Vogel, 1994). Water quality parameters amount of carbonate and bicarbonate was determined by acidimetric titrations and expressed in ppm as $\mathrm{CaCO}_{3}$ (Richard, 1954). $\mathrm{RSC}$ was calculated as the difference between sum of carbonate and bicarbonate and sum of calcium and magnesium and then expressed in milliequivalent per liter $\left(\mathrm{mEq} \mathrm{L} \mathrm{L}^{-1}\right)$. Boron, a toxic pollutant, content of water was determined by colorimetric method of analysis and expressed in ppm (Sarkar et al., 2014). Amount of total iron, a water quality parameter, was 
calculated by $\mathrm{KMnO}_{4}$ titrimetry method and expressed in ppm. Amount of chloride, a saline water contaminant, was determined by Mohr's titration method and expressed in ppm. Amount of sulphate, a water quality parameter, was determined by turbidimetric method followed by spectrophotometry at $440 \mathrm{~nm}$ and expressed in ppm. Nitrate, nitrite $-\mathrm{N}$, an organic pollutant, was analysed by Kjeldal distillation followed by titrimetry method and presented as ppm.

The content of Mineral oil-grease, as industrial organic pollutant, was anlysed by gravimetry method of analysis and presented in ppm (Khopkar, 2011). Phenol in a sample of water was determined by spectrophotometry method by using aminoantipyrine and presented in ppm (De, 2018). Analysis of anionic surfactants in polluted water sample were carried by spectrospectrometry technique by using methylene blue method and presented in ppm (De, 2010).

\section{DATA AND METHODS}

Analytical instruments, techniques for analysis of water from various sources are summarized in table 1.

\section{Table 1}

Analytical Techniques for Water Quality Parameters

\begin{tabular}{lll}
\hline Parameters & Analytical techniques/Instruments & Units \\
\hline Colour & P-C Visual comparison & P-C unit \\
Odour & Relative threshold odour & TON \\
Temperature & Thermometer & ${ }^{\circ} \mathrm{C}$ \\
Specific gravity & Gravimetry & $\mathrm{g} \mathrm{cm}^{-3}$ \\
Relative turbidity & Nephelometry & $\mathrm{NTU}$ \\
Suspended solid (SS) & Gravimetry & Ppm \\
TDS & Gravimetry & Ppm \\
TS & Gravimetry & Ppm \\
$\mathrm{p}^{\mathrm{H}}$ & p meter & $\mathrm{p}^{\mathrm{H}} \mathrm{unit}$ \\
EC & Conductivity meter & $\mu \mathrm{S} \mathrm{cm}{ }^{-1}$ \\
Alkalinity & Acid titrimetry & $\mathrm{Ppm}$ \\
Carbonate & Acid titrimetry & $\mathrm{Ppm}$ \\
Bicarbonate & Acid titrimetry & $\mathrm{Ppm}$ \\
Ca-Hardness & EDTA titrimetry & $\mathrm{Ppm}$ \\
Mg-Hardness & EDTA titrimetry & $\mathrm{Ppm}$ \\
\hline
\end{tabular}




\begin{tabular}{lll}
\hline Total hardness & EDTA titrimetry & Ppm \\
RSC & Titrimetry and difference & Ppm \\
Boron & Colorometry & Ppm \\
Iron & Titrimetry & Ppm \\
Chloride & Mohr's titrimetry & Ppm \\
Sulphate & Spectrophotometry & Ppm \\
Nitrate, nitrate-N & Titrimetry & Ppm \\
Mineral oil, grease & Gravimetry & Ppm \\
Phenol & Spectrophotometry : Aminoantipyrine & Ppm \\
Surfactants & Spectrophotometry : methyl blue & Ppm \\
\hline
\end{tabular}

\section{RESULTS AND DISCUSSION}

Analyzed physicochemical parameters of river water, stream water, irrigation water, bore well water and potable water collected in 15 October 2018 (28 Ashwin 2076) are presented in table 2 .

\section{Table 2}

Physicochemical Properties of Water from Various Sources

\begin{tabular}{|c|c|c|c|c|c|c|}
\hline Quality Parameters & $\begin{array}{l}\text { River } \\
\text { Water }\end{array}$ & $\begin{array}{l}\text { Stream } \\
\text { Water }\end{array}$ & $\begin{array}{l}\text { Irrigation } \\
\text { Water }\end{array}$ & $\begin{array}{l}\text { Bore Well } \\
\text { Water }\end{array}$ & $\begin{array}{l}\text { Potable } \\
\text { Water }\end{array}$ & $\begin{array}{l}\text { WHO Values for } \\
\text { drinking water } \\
\left(4^{\text {th }} \text { ed. } 2011\right)\end{array}$ \\
\hline Colour (P-C) & 30 & 10 & 25 & 5 & 5 & 5 \\
\hline Odour (TON) & 2 & 1 & 2 & 1 & 1 & - \\
\hline Temperature $\left({ }^{\circ} \mathrm{C}\right)$ & 16.0 & 16.5 & 16.3 & 18.0 & 17.0 & $12-25$ \\
\hline $\begin{array}{l}\text { Specific gravity ( } \mathrm{g} \\
\mathrm{cm}^{-3} \text { ) }\end{array}$ & 1.04 & 1.02 & 1.03 & 1.04 & 1.00 & \\
\hline $\begin{array}{l}\text { Relative turbidity } \\
(\mathrm{NTU})\end{array}$ & 25.0 & 10.0 & 15.0 & 5.0 & 5.0 & 10.0 \\
\hline $\mathrm{SS}(\mathrm{ppm})$ & 220.0 & 15.0 & 200.0 & 5.0 & 5.0 & \\
\hline TDS (ppm) & 200.0 & 60.0 & 200.0 & 215.0 & 55.0 & 600 \\
\hline TS (ppm) & 420.0 & 75.0 & 400.0 & 220.0 & 60.0 & \\
\hline $\mathrm{p}^{\mathrm{H}}$ ( $\mathrm{p}^{\mathrm{H}}$ unit $)$ & 6.8 & 7.0 & 6.9 & 7.3 & 7.0 & $6.5-8.5$ \\
\hline $\mathrm{EC}\left(\mu \mathrm{S} \mathrm{cm}{ }^{-1}\right)$ & 255.0 & 275.0 & 230.0 & 635.0 & 200.0 & 400.0 \\
\hline Alkalinity (ppm) & 70.0 & 72.5 & 75.5 & 114.0 & 80.0 & 500.0 \\
\hline
\end{tabular}




\begin{tabular}{lllllll}
\hline Carbonate (ppm) & 39.0 & 36.0 & 36.0 & 60.0 & 40.0 & 40.0 \\
Bicarbonate (ppm) & 81.33 & 76.25 & 76.25 & 128.0 & 76.25 & $150-200$ \\
Ca-Hardness (ppm) & 28.0 & 26.2 & 28.0 & 46.0 & 20.4 & 100.0 \\
Mg-Hardness (ppm) & 6.0 & 6.6 & 6.0 & 12.0 & 4.8 & 30.0 \\
Total hardness & 95.0 & 93.0 & 95.0 & 215.0 & 71.0 & 500.0 \\
(ppm) & & & & & & \\
RSC (mEq L -1$)$ & 0.733 & 0.59 & 0.55 & 0.80 & 0.98 & 0.98 \\
Boron (ppm) & 2.50 & 1.50 & 2.40 & 3.20 & 2.10 & \\
Iron (ppm) & 0.85 & 0.68 & 0.80 & 1.14 & 0.40 & 0.30 \\
Chloride (ppm) & 96.0 & 98.0 & 94.0 & 104.0 & 98.0 & 250 \\
Sulphate (ppm) & 16.4 & 14.0 & 16.0 & 22.42 & 12.20 & \\
Nitrate, nitrite- & 10.0 & 10.8 & 10.5 & 12.24 & 8.42 & 12.2 \\
N(ppm) & & & & & & \\
Mineral oil, grease & 0.12 & 0.09 & 0.15 & 0.01 & 0.05 & \\
(ppm) & & & & & & \\
Phenol (ppm) & 0.001 & 0.001 & 0.0014 & 0.001 & 0.001 & 0.001 \\
Surfactants( ppm) & 24.0 & 38.0 & 42.0 & 5.0 & 12.0 & \\
\hline Sorce: Resear & & & & & \\
\hline
\end{tabular}

Source: Researcher's calculation,, 2018

The colour and odour of water samples ranged from 5.0 - 30.0 platinum cobalt $(\mathrm{P}-$ C) unit and 1.0-2.0 TON respectively. The observed relative turbidity and suspended solids ranged from 5.0 -25.0 NTU and 5.0 - $220 \mathrm{ppm}$ respectively. The more observed value of color, turbidity and suspended solid for river water and irrigation water were due to presence of glacial milky white suspended colloidal particles and deflocculating complex soil particles. That is why the river is also known as Seti Gandaki river or milky white colored river. The observed temperature varied from $16-18{ }^{\circ} \mathrm{C}$ which was acceptable for Nepal's and WHO standard. The temperature of snow-river was lower than that of other sources. Due to the presence of more amount of dissolved solid and dissolved minerals, the specific gravity of bore well water and river water was more than that of other sources. It ranged from 1.0- 1.04 $\mathrm{gm} \mathrm{cm}^{-3}$. Similarly, TDS was highest for bore well water $(215 \mathrm{ppm})$ and minimum for potable water (55 ppm) but TS was greater for river water due to more amount of suspended solid resulting from continuous landslide and erosion of soil by strong current of river water. These values were within the permissible limit of WHO standard.

The water quality parameter, $\mathrm{P}^{\mathrm{H}}$, is an important indication of acidic or alkaline condition 
of water samples. $\mathrm{P}^{\mathrm{H}}$ was 7.0 for potable water and stream water and overall ranged from $6.8-$ 7.3 falling within the Nepal's and WHO water quality standard $6.5-8.5$ (Government of Nepal, 2062 BS; WHO, 2011). Slightly alkaline character of bore well water $\left(\mathrm{P}^{\mathrm{H}} 7.3\right)$ was due to presence of dissolved carbonates, bicarbonates and metal oxides. Electrical conductivity (EC) indicates the total amount of dissolved salt in water. Recorded electrical conductivity values ranged from 200 (Potable water) to $635 \mu \mathrm{S} \mathrm{cm}^{-1}$ (bore well water) remaining within their own WHO standard limits. WHO Guideline for irrigation water was $750-2250 \mu \mathrm{S} \mathrm{cm}^{-1}$ (Richard, 1954) and drinking water was $400 \mu \mathrm{S} \mathrm{cm}^{-1}$ (WHO, 2011).

Alkalinity character of water buffers acid rain and other acid wastes, preventing $\mathrm{P}^{\mathrm{H}}$ change of water that is harmful to aquatic life. Alkalinity of water is applicable for water treatment, water softening and control of corrosion due to acid but excess alkalinity of water also corrodes water supply pipes, rocks, metals, damage soil and then reduces crop yields (Khopkar, 2012). Alkalinity of water samples showed for between 70.0 -145.0 ppm which were below the respective WHO standard values. The observed values of carbonate and bicarbonate were $36.0-60.0 \mathrm{ppm}$ and $76.25-128.0 \mathrm{ppm}$ respectively indicating bicarbonate dominating character of water samples and both parameters were remained within the WHO standard limit. From the analysed five sample of water, bore well sample contained greater value of carbonate and bicarbonate indicating presence of mineral sources within the bore well. Higher concentration of bicarbonate in irrigation water increases $\mathrm{P}^{\mathrm{H}}$ value of dissolution of organic matter in the soil but much higher concentration increases toxicity and affect the element nutrition of plants (Al-Khashman et al., 2017).

The observed calcium hardness and magnesium hardness ranged from 20.4 to 46.0 $\mathrm{mg} \mathrm{L}^{-1}$ and 4.8-12.0 ppm respectively indicating calcium hardness dominating character of different sources of water. Total hardness varied from 71.0 to $215 \mathrm{mg} \mathrm{L}^{-1}$ as $\mathrm{CaCO}_{3}$ indicating these values within the WHO standard limit (500 ppm). The observed hardness of potable water was less $(71.0 \mathrm{ppm})$ and that of bore well water was more $(215.0 \mathrm{ppm})$ which may due to dissolution of lime stone, gypsum, dolomite and leaching process of other rocks within the bore well. Hardness order of samples was; bore well $>$ river water $=$ irrigation water $>$ stream water $>$ potable water. On the basis of hardness, potable water was soft $(0.0-75 \mathrm{ppm})$; river, irrigation and stream water was moderately soft $(75-150 \mathrm{ppm})$ and bore well water was hard $(150-300 \mathrm{ppm})$ but not very hard $(>300 \mathrm{ppm})$. The residual sodium carbonate (RSC) value of water represents the excess of carbonate $\left(\mathrm{CO}_{3}^{-}+\mathrm{H} \mathrm{CO}_{3}^{-}\right)$over the calcium ion $\left(\mathrm{Ca}^{2+}+\mathrm{Mg}^{2+}\right)$ and ranged from $0.55-0.98 \mathrm{me} \mathrm{L}^{-1}$ which remained within the safe scale (safe $\left.<1.2\right)$. Greater 
value of this irrigation quality parameter (RSC) forced hydrolysis of $\mathrm{Na}_{2} \mathrm{CO}_{3}$ which increases $\mathrm{OH}^{-}$ions and $\mathrm{P}^{\mathrm{H}}$ of soil (Al-Khashman et al., 2017).

In the present study, content of iron ranges from 0.4 for potable water to $1.14 \mathrm{ppm}$ for bore well water indicating greater amount of iron in all the water sample than that of permissible drinking water limit (0.30 ppm) of WHO (WHO, 2011). Unexpected more observed amount of iron (1.14 ppm) in bore well sample may due to either corrosion of iron pipe used in bore well or leaching of iron minerals inside the well. Recorded amount of chloride varied from 94.0 for irrigation water to $104.0 \mathrm{ppm}$ for bore well water which falls within the recommended drinking water standard value of WHO (250 ppm). Its value was minimum for irrigation water and maximum for bore well water. More chloride concentration in irrigation water is harmful for growing and sensitive plants (Kudesia \& Kudesia, 1998). The observed boron content of water samples ranged from $1.5-3.2 \mathrm{ppm}$ which were within the normal range listed in Tamil Nadu Agriculture University (TNAU, 2016).

The analyzed value of nitrate and nitrate- $\mathrm{N}$ in water varied from 8.42 to $12.24 \mathrm{ppm}$ which was within the standard recommended value of drinking water (WHO, 2011). The amount of industrial pollutant oil and grease in the water samples observed from 0.01 to 0.15 ppm indicating lowest amount in bore well water and highest amount in irrigation water. The content of toxic pollutant phenol in the samples of water ranged from $0.001-0.0014 \mathrm{ppm}$. These values were within the permissible limit of WHO $(0.002 \mathrm{ppm})$. The analysed amount of organic water pollutant surfactants observed from 5.0 to $42.0 \mathrm{ppm}$ indicating lowest amount in bore well water and highest amount in irrigation water. The greater amount of organic pollutants in irrigation water was due to direct flow of household, municipal, agricultural and industrial wastage to the canal of irrigation water in the dense polluted metropolitan.

\section{CONCLUSION}

Most of the physical and chemical parameters were remained within the permissible limit of WHO standard values. The unexpected glacial cream white color and turbid solids in river water was due to dissolution of white cream colored lime stone, marble, kaolinite, iron oxide and other minerals on the way of river. The analyzed amount of iron for all the samples was greater than that of WHO permissible limit for drinking water $(0.3 \mathrm{ppm})$ and the amount was greatest for bore well water which was due to rusting of iron pipe used in bore well station and presence of iron containing minerals inside the well circumstances. The analyzed amount of oil grease, phenol and surfactant were very low for bore well water, low 
for potable water and small notable for river water, stream water and irrigation water. On the basis of observed results, it could be concluded that water from potable source was soft water, water from river, stream and irrigation canal was moderately soft and that from bore well was hard. The analyzed result showed that water from bore well and potable source can be used for drinking and other purposes after iron treatment. Water from Seti Gandaki River, Kali stream and irrigation canal sources may also be used for bathing, washing, irrigation and industrial uses after proper treatment. Bore well water was less polluted from external contaminants than river water, stream water, irrigation water.

In the present study, most of the physicochemical properties were analyzed but not all of them. Some of organic pollutants were analyzed and all of microbiological species were not analyzed due to shortage of specific chemicals and efficient equipments in the laboratory. To obtain more exact and accurate results, analysis of all physicochemical parameters, all organic pollutants and all microbiological species for each water sample by using specific chemicals and efficient equipments are recommended so that the much more reliable data could be available for students, planners, government authorities and researcher communities. Based on the result of this study, it is highly recommended that the potable water, bore well water and surface water should be continuously monitored and protection measures must be implemented to alleviate the effect of metropolitan refuse, waste water, chemical fertilizers used in agricultural activities, hospital and industrial run off. In addition, the messages should be enlightened about the effect of pollution of water sources.

\section{ACKNOWLEDGEMENT}

I would like to express my gratitude to Campus Chief, Prithivi Narayan Campus, Assistant Campus Chief, Faculty of Science and Technology, and the Head, Department of Chemistry, Prithvi Narayan Campus Pokhara, Nepal for providing laboratory facility, essential advice, valuable suggestions and inspiration during the research work. I would offer my sincere thanks to prof. Dr. Vikash Kumar K. C. and prof. Dr. Shobhakanta Lamichhane for continuous encouragement and valuable suggestions throughout the process.

\section{REFERENCES}

Al-Khashman, O. A., Alnawafleh, H. M., Jrai, A. M. A., \& A-Muhtaseb, A. H. (2017). Monitoring and assessing of spring water quality in southwestern Basin of Jordan. Open Journal of Modern Hydrology, 7, 331-349. 
Ambasht, R. S., \& Ambasht, P. K. (2009). Environment and pollution (4 ${ }^{\text {th }}$ ed.). CBS Publishers and Distributors.

APHA. (1992). Standard methods for the examination of water and waste water (18 ${ }^{\text {th }}$ ed.). American Public Health Association.

APHA. (1985). Standard methods for the examination of water and waste water. American Public Health Association.

De, A. K. (2018). Fundamentals of water pollution. Scientific International Pvt. Ltd.

De, A. K. (2015). Environmental chemistry (7 $7^{\text {th }}$ ed.). New Age International Publisher.

Government of India. (2011). Methods manual: Soil testing in India. New Delhi: Department of Agricultural \& Co-operation Ministry of Agriculture, Government of India.

Government of Nepal. (2062). National drinking water quality standard. Ministry of Land Reform and Management.

Heath, R. C. (2004). Basic ground water hydrology, USGS Water Supply Paper 2220

Jain, S. K., \& Jain, S. K. (2014). Conceptual chemistry. S. Chand and Company Pvt. Ltd.

Khapkar, S. M. (2011). Environmental pollution analysis (2 ${ }^{\text {nd }}$ ed.). New Age International Publishers.

Kudesia, V. P., \& Kudesia, R. (1998). Water pollution (4 ${ }^{\text {th }}$ ed.). Pragati Publication.

Lekhak, H. D., \& Lekhak, B. (2009). Natural resource conservation and sustainable development in Nepal ( $3^{\text {rd }}$ ed.). Kshitiz Publication.

Oregon State University (1978). Methods of soil analysis used in the soil testing laboratory at Oregon State University. Agricultural Experiment Station.

Richard, L. A. (1954). Diagnosis and improvement of saline and alkaline soils. Agri-Handbook No. 60 United States Department of Agriculture.

Sarkar, D., Sheikh, A. A., Batabyal, K., \& Mandal, B. (2014). Boron estimation in soil, plant and water samples using spectrophtometric methods. Communications in Soil Science and Plant Analysis, 45 (11), 1538-1550.

Shukla, D., Bhadresha, K., Jain, N. K., \& Modi, H. A. (2013). Physicochemical analysis of water from various sources and their comparative studies. IOSR Journal of Environmental Science, Toxicology \& Food Technology (IOSR-JESTFT), 5 (3), 89-92.

Sthapit, R. P., \& Sthapit, M. K. (1998). Essential physical chemistry. Talaju Prakashan.

Subedi, T. (2018). Analysis of underground water of different hospitals in Pokhara. Himalayan Scientific Journal, 9, 64-69.

Tamil Nadu Agricultural University. (2016). Suitability of water for irrigation: Irrigation 
management. Tamil Nadu Agricultural University.

Venkateswarlu, K. S. (1996). Water chemistry. New Age International Pvt. Limited.

Vogel, A. I. (1994). Vogel's text book of qualitative chemical analysis. Bath Press Ltd.

Warner, N. R., Levy, J., Harpp , K. S. \& Farruggia, F. T. (2008). Drinking water quality in Nepal's Kathmandu Valley: A survey and assessment of selected controlling site characteristics. Hydrology Journal, 16, 321-334.

WHO (2011). Nitrate and nitrite in drinking water: Background document for development of WHO guideline for drinking water quality. World Health Organization Press. 